УДК 94 (571.150).084

ББК 63.3 (2 Рос-4 Алт) 63

\title{
Вопросы продовольственного снабжения населения в 1960-1980-е гг. в материалах Государственного архива Алтайского края*
}

\author{
Е.В. Демчик, Г.А. Гряникова
}

Алтайский государственный университет (Барнаул, Россия)

\section{Issues of Food Supply of the Population in the 1960s-1980s in the Materials of the State Archive of the Altai Territory}

\author{
E.V. Demchik, G.A. Gryanikova \\ Altai State University (Barnaul, Russia)
}

Представлен опыт работы с документами из фондов Государственного архива Алтайского края, относящихся к вопросу продовольственного снабжения населения края в 1960-1980-е гг. Проведен анализ степени объективности этого вида источников, полноты содержания, осуществлена попытка оценить роль архивных материалов в изучении истории торговли продовольственными товарами и предприятий общественного питания в отдельных городах и крае в целом. Сметы и штатные расписания финансовых учреждений и промышленных предприятий городов края освещают степень их взаимосвязи с торговыми организациями, структуру и уровень развития городских отделов торговли плодоовощными и пищевыми товарами, как следствие, организацию розничной торговой сети. Сделан вывод о том, что несмотря на высокую степень следования действующей идеологии при составлении текстов документов того периода, приведение цифровых показателей к абсолютным в соответствии с установленными государственными планами, не стоит исключать ценность имеющегося материала в изучении актуальных проблем системы продовольственного снабжения, качественного уровня обслуживания и количественных показателей потребления продуктов. Однако необходимо находить подтверждение содержащейся в финансовых и отчетных документах информации в других источниках по теме исследования.

Ключевые слова: продовольственное снабжение, общественное питание, советская торговля, повседневность, архивный фонд, Алтайский край.
The article presents the experience of working with the documents from the funds of the State Archive of the Altai Territory related to the issue of food supply of the population in the 1960s-1980s. The authors analyse of the degree of objectivity of this kind of sources, content completeness and make an attempt to estimate the role of archival materials in the study of the history of trade by food goods, catering establishments in separate cities and the territory as a whole. The budgets and staff registers of financial institutions and industrial enterprises of Altai cities cover the extent of their relationship with trade organizations, the structure and level of development of the city trade departments of fruit and vegetable and food products and, as a result, the organization of the retail trade system. The authors conclude that despite the high degree of pursue to the ideology in drawing up texts of documents those period, the enforcing of digital indicators to absolute in accordance with the established Gosplan (state plan), one should not exclude the value of the available material in studying topical issues of the food supply system, qualitative level of service and quantitative indicators of product consumption. However, it is necessary to confirm the information contained in the financial and reporting documents in other sources on the topic of the study.

Key words: food supply, catering industry, Soviet trade, daily life, archival fund, Altai territory.

DOI 10.14258/izvasu(2019)6-03

*Исследование выполнено при финансовой поддержке РФФИ в рамках гранта № 19-49-220005 «Торговля и товарное снабжение Алтайского края в 1960-1990-е гг.: от плановой экономики к рыночной». 
Продовольственное снабжение как вид хозяйственной деятельности относится к важной составляющей истории социально-экономических процессов. Разностороннее исследование механизма продовольственного снабжения жителей Алтайского края в 60-80-х гг. ХХ в. и реализации государственной политики в отношении этого вопроса представляется актуальным в связи с неоднозначностью имеющихся данных об уровне производства продуктов питания и качестве потребляемых продовольственных товаров. Как правило, показатели пищевой промышленности и результаты деятельности предприятий общественного питания рассматриваются с экономической точки зрения в отрыве от личного потребления и спроса, что определило низкую изученность качества жизни населения в рамках истории повседневности.

Вопросы качества товарного снабжения жителей Алтайского края в 1960-1980-е гг., стратегии развития торговли и общественного питания, объема производства продуктов питания и уровня их потребления в историческом плане исследовались в ограниченном числе научных работ. Отдельные аспекты развития сельского хозяйства, производства продовольствия и организации общественного питания представлены в историографии по экономической истории. Продовольственное обеспечение населения исследовалось прежде всего в рамках изучения феномена товарного дефицита [1;2]. Имеются и региональные исследования уровня жизни, однако без учета динамики продовольственного потребления продуктов питания населением Алтайского края [3; 4]. Интерес для изучения поставленной проблемы в рамках региона, несомненно, представляют энциклопедические статьи по вопросам промышленности, развития экономики и торговли [5, с. 295-297; 6, с. 202-203], а также научные исследования по истории Алтайского края [7-9; 10, с. 59-75]. В научном издании «История Алтая» коллективом профессиональных историков рассматриваются ключевые социально-экономические процессы новейшей эпохи истории Алтая. Для изучаемого периода интерес представляет статья Д.С. Орлова, посвященная развитию аграрного сектора второй половины $\mathrm{XX}$ в. и результатам этого развития в отношении продовольственного снабжения и общественного сектора сельского хозяйства региона [11, с. 173-210]. Основные аспекты развития промышленности края подробно изложены в работе Е.Н. Курсаковой, в которой автор приходит к выводу, что особенности структуры экономики региона определили низкое стартовое положение края накануне перехода к рыночной экономике [12, с. 211-248]. К вопросу функционирования аграрно-промышленного комплекса, который неразрывно связан с производством продовольственных товаров, Е.Н. Курсакова обращалась и в другой своей статье, где комплексно рассматривается развитие предприятий в экономических и природных условиях на территории края [13, с. 111-118]. В то же время в работе нет отсылок к связи производства и потребителя. Небольшого круга региональных исследований недостаточно для составления целостной картины о состоянии продовольственного обеспечения населения. В них лишь частично отражаются производственные показатели предприятий края, динамика расходов на потребление, абсолютное потребление отдельных продуктов в рамках изучения проблем товарного дефицита без проведения дальнейшего анализа с целью выявления взаимосвязи промышленного производства и личного потребления.

Для комплексного осмысления системы продовольственного снабжения региона в 1960-е - начале 1980-х гг. в дополнение к научной литературе необходимо привлечение информации из первоисточника, а именно документов Государственного архива Алтайского края, содержащих разносторонний материал об обеспечении продовольствием городского и сельского населения. В таком случае историко-проблемное и аналитическое понимание прошлого составляет основу методологии изучения основных черт организации розничной торговой сети и предприятий общественного питания. Исследование включает элементы экономического изучения регионального снабжения. Согласно историческому подходу осмысления проблем система снабжения рассматривается в тесной взаимосвязи с общими процессами развития советской экономики. При работе с неопубликованными данными архивных источников использовались методы сбора, систематизации и анализа информации, историко-сравнительный метод при сопоставлении данных о результатах финансовой деятельности и историко-генетический метод для определения специфики социально-экономического развития региона через особенности торгового снабжения.

Материалы Фонда Р-784 Барнаульского городского Совета народных депутатов свидетельствуют о том, что основой продовольственного снабжения являлась розничная торговая сеть. Магазины, палатки, киоски, ларьки находились в подчинении городских отделов торговли - Хлебторга и Горплодоовощеторга [14, л. 117-118; 15, л. 231]. Сметы и штатные расписания финансовых учреждений и промышленных предприятий Барнаула позволяют судить об уровне их развития и взаимосвязи с торговыми организациями, о структуре городских отделов торговли пищевыми товарами. Такая категория товаров, как продукты питания, занимала первичное место в личном потреблении населения. В 1968 г. на долю пищевой промышленно- 
сти приходилось 52 \% от общего числа налоговых поступлений с товарооборота в бюджет Барнаула $[16$, л. 1].

Ведущую роль питания в личном потреблении подтверждают и сведения годовых статистических таблиц относительно состава семей и денежных доходов и расходов населения Алтайского края, хранящиеся в Фонде Р-718 Управления госкомитета по статистике. В конце 1970-х гг. расходы на питание на 100 семей рабочих промышленности Алтайского края в среднем занимали 32,3 \% (в том числе на общественное питание - 6,4 \%) в общем числе расходов $[17$, л. 1]. Расходы на питание на 100 семей сельского населения в среднем составляли 18,5 \% от общего числа расходов (в том числе на общественное питание $-1,2 \%)[18$, л. 82$]$.

Стоит учитывать, что имело место небольшое увеличение розничных цен на продукты в предприятиях общепита, подведомственных краевому Управлению общественного питания. За пять лет рост составил $11,4 \%$ [19, л. 57; 20, л. 28]. Несмотря на это они не превышали средних розничных цен государственной и рыночной торговли, что подтверждается цифровыми данными конъюнктурных обзоров краевого управления торговли [21, л. 299].

Помимо ценовых данных, Фонд Р-926 содержит сводные годовые и квартальные статистические отчеты управления торговли, планы товарооборотов, обзоры об удовлетворении товарного спроса населения. Полученные при работе с фондом сведения позволяют проследить неравномерность в снабжении определенных категорий продовольственных товаров. Конъюнктурный обзор Алтайского края по 1967 г. содержит сведения о бесперебойности торговли молочными и мясными продуктами, хлебобулочными изделиями. Но зафиксированы перебои в торговле сахаром, кондитерскими и макаронными изделиями, сливочным и растительным маслами [21, л. 29-30, 195-196].

Согласно планам реализации продукции и данным по объему промышленного производства и товарообороту, содержащимся в Фонде Р-1033, наблюдалось не только количественное, но и постепенно качественное улучшение рациона в связи с ростом доли животной пищи. Продовольственный товарооборот в течение 1971 г. вырос на 6,3\%. В то время как рост реализации мяса и птицы составил 16,7 \%, колбасных изделий $-21,4 \%$, молока и молочных продуктов - 8,8 \% [22, л. 43-44]. Росту продовольственного потребления способствовала такая сфера обслуживания, как общественное питание, занимая второе место по объему товарооборота после местных торгов [23, л. 106-108]. При общей положительной динамике развития сети общественного питания и регулярном выполнении плана розничного товарооборота в документах фонда отмечены недостатки в работе по выполнению отдельных плановых заданий, установленных государством [24, л. 2, 9, 68-69].

Предварительное рассмотрение планов отдельных предприятий, учреждений и организаций, расположенных на территории города, осуществляли плановые комиссии городских исполнительных комитетов городского Совета депутатов трудящихся. Анализ сохранившихся в Фонде Р-1037 планов, отчетов и справок по итогам развития местного хозяйства позволяет проследить темпы развития торговой сети и предприятий общественного питания городского и краевого подчинения, их количество и степень соответствия предъявляемым требованиям [25, л. $14-15 ; 26$, л. 35].

Тресты столовых городов края с 1967 г. находились в подчинении Управления общественного питания. В его функции входили организация планово-финансовой работы трестов столовых и контор общественного питания, разработка и составление планов размещения и строительства предприятий, внедрение новых форм обслуживания, подготовка и переподготовка кадров. Фонд Р-1573 содержит производственные и финансовые планы по товарообороту, сводные годовые бухгалтерские и статистические отчеты трестов столовых, а также данные о количестве предприятий, распределенных по местоположению, методу обслуживания, техническому оснащению. Полученные данные позволяют судить о состоянии общественного питания в Барнауле, Бийске, Рубцовске, Славгороде и деятельности по развитию и улучшению данной отрасли народного хозяйства. На 1 января 1968 г. продажу готовой пищевой продукции населению Алтайского края осуществляли столовые $(48,4 \%)$, буфеты (46,6 \%), домовые кухни, рестораны, вагоны-рестораны, кафе, закусочные, две фабрики-кухни, один автомат [19, л. 112-113]. Данные по количеству предприятий края и динамике их развития нашли подтверждение в статистических сборниках рассматриваемого периода. Количество предприятий общепита с 1968 по 1971 г. увеличилось в 1,5 раза, количество посадочных мест - в 1,3 раза [27, с. 411]. Обеспеченность жителей сетью предприятий общественного питания составила 19 шт. на 10 тыс. чел., что превышало общесоюзный показатель (11 шт.). Количество посадочных мест в расчете на 10 тыс. чел. на 8\% превышало показатель в расчете по СССР [28, с. 17]. Сметы по регистрации штатов позволяют охарактеризовать состав работников торговли по численности, занимаемым должностям и заработной плате. В 1972 г. количество работников предприятий общепита Алтайского края составляло 13129 чел., к началу 1980-х гг. - 14580 чел. [29, л. 10].

Стоит признать частичную недостоверность советской статистики в связи с искусственным за- 
вышением отдельных показателей и изложением в официальных документах информации, которая не отражала действительного уровня обеспеченности граждан потребительскими товарами. Однако подробное исследование имеющегося материала дает возможность изучить деятельность советской торговли с разных сторон с целью наиболее объективного представления о сложившейся социальноэкономической ситуации. Нарушения по соблюдению правил торговли и качеству товаров выявлялись посредством комплексных и ежеквартальных проверок, проводимых Управлением госинспекции. В документах Фонда Р-1118 подробно описаны случаи обмана в трестах столовых Барнаула за счет нарушения цен, обмера, обвеса, обсчета, занижения калорийности, использования неисправных весоизмерительных приборов [30, л. 7-18]. Помимо обозначенных нарушений, основными вопросами продовольственного снабжения оставались формирование ассортимента, недостаточная изученность спроса населения и отсутствие отдельных продуктов питания [30, л. 9]. Особую проблему составляло низкое качество производимой продукции, несмотря на общепринятое мнение о высоком качестве товаров, производимых на предприятиях пищевой промышленности Алтайского края. Частым явлением было низкое качество хлебобулочных и кондитерских изделий вследствие грубого нарушения технологического процесса, не соответствующего нормам сырья, наличия посторонних предметов в хлебе, упаковки товара в нестандартную тару
[31, л. 15-26, 39-47]. К дефектам сахара относились увлажненность и загрязненность ворсом от мешков, качество рыбы снижали «белобочка и рвань», плодоовощных консервов - ржавление металлических крышек и образование бактерий вследствие недостаточной стерилизации и нарушения норм хранения [31, л. 51-52, 75-81].

Таким образом, анализ содержащихся в фондах финансовых учреждений и торговых организаций сведений позволяет характеризовать систему продовольственного снабжения населения Алтайского края в 1960-1980-е гг. не только с положительной стороны. Наиболее достоверной представляется информация об уровне цен, показателях развития производства, количестве и формах предприятий общественного питания и магазинов, предоставляющих населению продовольственные товары. Отражение нашли факты о перебоях в снабжении определенными товарами и нарушениях в соблюдении правил торговли. С целью выявления основных черт организации розничной торговой сети и предприятий общепита следует обращаться к иным видам источников, таким как периодическая печать и источники личного происхождения. Несмотря на субъективный характер газетных статей и материалов интервью, привлечение дополнительных источников откроет больше возможностей для комплексного изучения экономического развития региона и составления целостного представления о сложившейся системе продовольственного снабжения.

\section{Библиографический список}

1. Мендкович Н.А. Питание в СССР в «Эпоху застоя» (1960-1980-е гг.) // Актуальная история. URL: http:// actualhistory.ru/zastoi_foods (дата обращения: 11.05.2019).

2. Уровень жизни городского населения РСФСР (1946-1991 гг.) в отечественной историографии / под ред. М.А. Клинова. Екатеринбург, 2014.

3. Манько Н. История питания новосибирцев от ковриги до пармезана // Новосибирские новости. URL: http://nsknews.info/news/144123 (дата обращения: 12.05.2019).

4. Мартюшов Л.Н. Потребление продуктов питания населением Урала в 1950-1980-е гг. // Четвертые Татищевские чтения : сб. науч. ст. Екатеринбург, 2003.

5. Торговля // Барнаул : энциклопедия. Барнаул, 2000.

6. Экономика. Торговля // Энциклопедия Алтайского края: в 2-х т. / редкол.: В.Т. Мищенко (гл. ред.) и др. Барнаул, 1995. Т. 1.

7. Зиновьев В.П. Революция массового потребления в СССР // Экономическая история Сибири XX в. : ма- териалы Всероссийской научной конференции : в 3 ч. (30 июня - 1 июля 2006 г., Барнаул) / под ред. Е.В. Демчик. Барнаул, 2006. Ч. 1.

8. Очерки истории Алтайского края. Барнаул, 1987.

9. Прохожев А.А. Организация управления народным хозяйством Алтайского края в 1970-1980-е гг. // История Алтайского края. XVIII-XX вв. Науч. и документ. материалы / редкол.: Т.К. Щеглова (отв. ред.), А.В. Контев. Барнаул, 2004.

10. Савицкий И.М. Совнархозы Сибири (1957-1965 гг.) // Экономическая история Сибири $\mathrm{XX}$ века : материалы Всероссийской научной конференции : в 3 ч. Барнаул, 2006. Ч. 3.

11. Орлов Д.С. Аграрный сектор Алтайского края во второй половине ХХ в.: от освоения целины к Продовольственной программе // История Алтая: в 3-х т. T. 3: Алтай в новейшую эпоху (XX - начало XXI века) / под ред. Е.В. Демчик. Барнаул ; Белгород, 2019. 
12. Курсакова Е.Н. Промышленность Алтайского края во второй половине 1940-х - первой половине 1980-х гг. // История Алтая : в 3-х т. Т. 3: Алтай в новейшую эпоху (XX - начало XXI века) / под ред. Е.В. Демчик. Барнаул ; Белгород, 2019.

13. Курсакова Е.Н. Становление и развитие Алтайского края как аграрно-промышленного комплекса (1970-1985 гг.) // Вестник Томского государственного университета. 2018. № 432. DOI:10/17223/15617793/432/14.

14. Государственный архив Алтайского края (ГААК). Ф. Р-784. Оп. 3. Д. 247.

15. ГААК. Ф. Р-784. Оп. 3. Д. 206.

16. ГААК. Ф. Р-784. Оп. 4. Д. 321.

17. ГААК. Ф. Р-718. Оп. 25. Д. 753.

18. ГААК. Ф. Р-718. Оп. 25. Д. 773.
19. ГААК. Ф. Р-1573. Оп. 1. Д. 4.

20. ГААК. Ф. Р-1573. Оп. 1. Д. 72.

21. ГААК. Ф. Р-926. Оп. 3. Д. 78.

22. ГААК. Ф. Р-1033. Оп. 5. Д. 472.

23. ГААК. Ф. Р-1033. Оп. 5. Д. 784.

24. ГААК. Ф. Р-1033. Оп. 5. Д. 452.

25. ГААК. Ф. Р-1037. Оп. 4. Д. 3

26. ГААК. Ф. Р-1037. Оп. 4. Д. 12.

27. Народное хозяйство СССР, 1922-1972 гг. : стат. ежегодник. М., 1973.

28. Торговля СССР : стат. сборник. М., 1989.

29. ГААК. Ф. Р-1573. Оп. 1. Д. 97.

30. ГААК. Ф. Р-1118. Оп. 4. Д. 11.

31. ГААК. Ф. Р-1118. Оп. 3. Д. 2. 